\title{
INSTAGRAM: HOW DO STUDENTS VIEW ON IT IN SPEAKING CLASSROOM
}

\author{
${ }^{1}$ Puspita Devi \\ Universitas Baturaja, Sumatera Selatan, Indonesia \\ Devi.fisipunbara@gmail.com \\ ${ }^{2}$ Bianca Virgiana, \\ Universitas Baturaja, Sumatera Selatan, Indonesia \\ virgiana.bianca@gmail.com \\ ${ }^{3}$ Merita Auli \\ Universitas Baturaja, Sumatera Selatan, Indonesia \\ meritayunizir@gmail.com
}

\begin{abstract}
The emergence of the 4.0 era requires the world of education to adapt to technology. Practicing and learning English can take the advantage of the sophisticated technology, especially applications that can be downloaded from students' smart phone. Students acknowledge that English learning done in the classroom is easy for them to forget because it is rarely used in everyday life. Practices done in the classroom do not have enough time for all students to speak English, and students are less motivation to speak English outside the classroom. Integrating Instagram into the process of teaching English speaking is believed could motivate students to speak and increase their speaking ability. Various features on Instagram can help students in doing assignments. Tasks may be packaged attractively within the variety of videos based on a certain theme and uploaded to Instagram. This study aimed to determine students' perceptions related to the use of social media Instagram in learning English speaking. This descriptive study used forty-four students Communication Science in academic year 2019/2020 who took Bahasa Inggris Keahlian. To determine students' perceptions, researchers used questionnaire adopted from Dornyei, 2011. The results of the study showed a positive or good response on students' perceptions towards the use of Instagram in learning English Speaking. Furthermore, Instagram can be used as another medium in teaching speaking. This is strengthened by the increase in self-confidence, learning motivation, and student interest in speaking in English.
\end{abstract}

Keywords: Learning English Speaking, Instagram, Students’ Perception.

\section{INTRODUCTION}

Currently, the world is feeling the impact of the Covid 19 pandemic, one of which is within the education sector. Educators must be ready to make sure that teaching, and learning activities continue, while students are at home. Online learning is an alternate that may be used in the educational process as an innovative use of recent media. One of the educational concepts can be done using social media like Whats up group,
Instagram, telegram, zoom, Edmodo and Google classroom or other learning media. Thus, a situation like this becomes a chance for English educators to transform learning methods from face-to-face to online through the media of Instagram in developing students' speaking skills. Therefore, educators can make sure that students follow the educational process at the same time. 
The need for the use of English is increase, it can be seen from the use of vocabulary when speaking in public or writing in various content on social media. Language is a human communication tool that may be used in both verbal and nonverbal forms, as is the case with English. Johnson and Morrow are quoted in Nirmawati (2015) as saying that speaking, which is better known as oral/verbal communication, is an activity that involves two or more people in which the listener and speaker must react to what they hear and at the subsequent level contribute / respond to it. Not only does it form grammatically correct sentences, but also covers broad areas like mechanical, functional, pragmatic, and social interactions. (Nirmawati, 2015: 5)

In the process of formal and informal activities, English is used as a second language for daily interactions. According to Jack C. Richard (2002: 201), the most important presentation for college students learning English is to develop their speaking skills. Therefore, speaking does not only depend upon the ability to master vocabulary, but also must have adequate grammar knowledge. Speaking is an important a part of English language skills that have to be emphasized within the learning process.

Practically, the use of English language skills has mostly been applied to universities in Indonesia. Students are required to possess a TOEFL certificate as one of the requirements for the thesis trial. Besides that, it can also be used as a language within the world of labour which may be another value during job selection. In practice, companies need those that have certain skills to take action and also English to communicate and support actions. This is supported by the World Bank (2010, p. 34) that core skills, like mathematics and literacy, computer skills, thinking skills, English language skills and behavioural skills are important for Indonesian workers. Additionally, Hirose (1992) claims there are still many college graduates working in companies that lack basic skills.

In recent years, companies, and offices in Indonesia has considered the necessity for public speaking skills for his or her staff. Companies want their staff to be able to communicate effectively and efficiently to support their career promotion and cooperation.Additionally, the era of globalization forces companies to expand their projects not only in Indonesia, but also to other countries. By having this international scope of labour, it's clear that corporate needs staff who can speak English well. It may be concluded that English is not only for students majoring in English but also for students majoring in aside from English, including students of Communication Science at the University of Baturaja.

Based on pre-observational researchers, most of the students of Communication Science face several problems within the learning process of the speaking class within the English, course, including a sense of fear when there's a blunder in speaking before of the class, lack of understanding of vocabulary in English in order that it is difficult to say, a scarcity of selfconfidence. In addition, students acknowledge that English learning done in the classroom is easy for them to forget because it is rarely used in everyday life. Practices done in the classroom do not have enough time for all students to speak English, and students are less motivation to speak English outside the classroom. In line with this statement, Sari (2017) and Alnathalah (2016) stated that in their 
research there have been several problems in speaking like difficulty in expressing something, feeling afraid when something went wrong, anxiety, and lack of self-confidence. Therefore, to beat existing problems, educators must be ready to apply the proper methods to assist students

\section{LITERATURE REVIEW}

\subsection{Teaching English Speaking}

The ability to speak represents language skills that have got to be mastered by an individual, especially students who are intellectual candidates. Many of them have been writing skills, but don't seem to be good at speaking. During this case the flexibility to talk in official forums or publicly, is not just talking. The flexibility to speak is commonly neglected because there's an assumption that speaking ability is often obtained naturally so not many educators teaches.According to Tarigan, speaking is the ability to precise articulated sounds or words to specific, express, and convey thoughts, ideas, and feelings (Tarigan, 2013: 15).. Within the Expertise English course, students are taught speaking techniques. Speaking is a vital a part of English language skills that have to be emphasized within the teaching and learning process within the classroom. Perlandose in Nunan, the mastery of speaking skills is the most vital aspect of learning a second language or foreign language, and success is measured regarding the ability to have a conversation in this foreign language. (Nunan, 1992: 23).

\subsection{Instagram}

Instagram was launched in October 2010 and gained popularity boosting over 300 million actives users in 2015 (Kelly, 2015). It is one in all the social media tools originally designed for understand and master speaking skills in English, like integrating social media Instagram in learning speaking. Therefore, the researchers were motivated to conduct the research because they intended to know students' perception towards the use of Instagram in Teaching English Speaking

Johnson and Morrow are quoted in Nirmawati (2015) stated that speaking which is best referred to as 'oral communication,' is an activity that involves two or more people in which listeners and speakers must react to what they hear and at the following level contribute / answer it. Not only does it form grammatically correct sentences, it also covers broad areas like mechanical, functional, pragmatic, and social interactions. In addition, Zhang (2009) argues that speaking skills remain the foremost difficult skill for many English learners to master, which they're still incompetent at speaking orally in English with people. Additionally, Ur(1996) stated that obstacles like, worrying about making mistakes, not knowing what to mention, and using the tongue are some samples of problems in classroom speaking. Referring to the reason above, it will be concluded that the event of communicative skills can only occur if students have the motivation. Therefore, the opportunity to precise their own identity and related to those around them (Littlewood, 1981). Thus, teachers have the responsibility to arrange students as best they'll to talk English.

mobile use through application. Instagram's users can perform some functions: post content, add captions, tag users, add location, add hash tag, follow other users, check feeds, add 
comments, like contents, explore other users, collect contents online, and send direct messages. People can leave discuss a post by click on the microscopic comment bubble beneath the post and former comments. This can open up a comment box where message is typed, and by sending click "send" to upload the comment. Comments can also be gotten when the videos are shared to other sites like Facebook or twitters.

In fact, social media networks attracted the attentions of educator. Thanks to recognition and use of those networks among young adults, especially with the rise of the internet connected smart phones (Bal\&Bicen, 2017). Given the excessive reputation of social media use, varieties of researches are administered to demystify employment of social media Instagram for tutorial purposes. Concerning learning, Handayani (2016) argues that it will be used as a source for applying variety of activities in language classrooms like digital storytelling, grammar activities through photos, role plays, reading, speaking activities through videos, etc.

In addition, Mansor and Rahim (2017) claimed Instagram was an efficient tool for students' interactions, whereas discussing task-related content. Besides, Listiani (2016) in her research revealed that Instagram promoted a much better understanding of college students with high and low motivation. Moreover, Al-Ali (2014) and Wiktor (2012), claimed Instagram has potential to be a acquisition tool regarding language skills. When pictures or videos are uploaded and shared with the scholars followed by questions from the teachers, the scholars are encouraged to use their language skills. Since internet becomes increasingly mobile, it may be used almost in everywhere, such as in lecturer' hall, computer room, classroom, at home, on the thanks to school, or in internet cafe. Thus, these make Instagram more tempting to be considered and utilized as a learning tool.

The emergence of

Instagram symbolized a form of technological progress as evidenced by the rise in Instagram, users per annum. Instagram may be a photo sharings application that enables users to require photos, apply digital filters, and share them on various social networking services, including Instagram's own. Social media Instagram is liked by many users because it has the benefit and speed of uploading various photos and videos with various filter effects available on the Instagram feature. The features of Instagram, namely:

a. Followers (Followers) Followers is a very important feature, where the amount of likes from followers greatly affects recognition of uploaded photos on the account.

b. Uploading Photos and videos (posts) The advantage of Instagram is that it's an area to upload and share photos with other users. When uploading photos or videos, usually users also can write a title or description of the photo in line with the user's wishes. Users also can provides a label to the photo title, as an indication to group the photos into a category.

c. Camera Photos that are taken through the Instagram application are often saved. The use of the camera via Instagram may directly use the prevailing effects to regulate the photo coloring desired by the user.Efek (Filter)

d. Instastory

Instastory stands for Instagram 
stories. Instastory is one in every of Instagram's features that allow its users to share photos or videos which will be deleted automatically within 24 hours afterwards. Within the Instastory fe ature there also are effects that may entertain its users.

e. Photo label (Hashtag) This label will be employed in any sort of communication related to the photo, itself. Users can enter their name, the place where they took the photo, to announce an incident, to point that the photo is participating during a competition,

\subsection{The use of Instagram in teaching English speaking}

Social media offer a variety of platforms for educators to use in teaching English. In line with this, Sheldon was quoted in Apriyati et al (2018) as saying that truly learning to use social media within the classroom is fun, but not many teachers apply it, and a few of them use social media inappropriately, therefore students feel that the teachers has to be more interactive and thoughtful. Technology changing the atmosphere of teaching and learning can provide versatile decisions and choices. For instance, the net provides many opportunities for students, educators, and administrators to try to their schoolwork and their work anytime and anywhere (Greenhow, 2011). Then the net has also become increasingly mobile, and may be used anywhere, such as within the lecturer room, computer room, classroom, at home, on the thanks to school, or in an online café. Students explicitly form up an outsized proportion of social media network users. Lenhart, Purcell, Smith, and Zickhur (2010) found that 72 out of all schools students have social media or to point that the photo was produced by a member of the Instagram community. Photos that are uploaded is put during a label that matches the knowledge associated with the photo.

f. Geotagging After entering the photo title, the subsequent feature is Geotag. This feature will appear when the users activate their GPS. Thus, Instagram can detect the placement where Instagram users are located. Geotagging users may be detected after they have taken or uploaded a photograph. (Nasrullah, 2015: 103)

with forty-five schools students using social media sites a minimum of once every day.

In the English course, social media Instagram is employed as a medium for presenting the assignments of communication science study program students. Students of Communication Science gave the intervention for about three months or in 12 meetings (including pre-test and post-test). They were learned and practice speaking with different topic for 10 times. With the topic that was familiar to them, they learned how to construct the content or message that they wanted to delivery, and they learned and practiced how to deliver the message well. They did not feel under pressure in doing the speaking task, since they had much time to prepare before posted it on their Instagram account. They had 24 hours to prepare their video, and they manage these times to construct the content, design the concept, and edit the video.

In addition, some researchers have revealed variety of benefits achieved through recording activity for EFL learners. Okada, et al. (2017) examined the effect of using video recordings of student presentations within the English 
as a far off language (EFL) classroom. The findings show that the students were able to develop strategies for a way to deliver an address successfully and gain self-worth in improving their English presentation skills within the classroom. A video recording activity helped EFL learners to boost their oral performance in some ways. They could evaluate their performance and do self reflection by watch back the videos. Students have the chance to judge and do self reflection by watching their videos and see how they performed, and what may be improved in future practices. Moreover, by evaluating their video, students become more critical on their abilities (Akdeniz, 2017). It made students get a longer time to check and helped students study again and again. They ready to review the aspect of speaking several times.Mansor and

\section{RESEARCH METHOD}

This research is a descriptive study with the data collection techniques using a questionnaire. Descriptive research is research that describes things that are currently applicable, while according to the sort of information and processing methods that are numerical and analyzed using statistical tests, they are classified in quantitative research. The score obtained was then analyzed using descriptive statistical techniques. Consistent with

Creswwel (2012: 43), the population is all research subjects. The population during this study were the students of the fourth semester majoring in Communication Science; University of Baturaja within the 2019/2020 academic year.The whole population is 50 students consisting of two classes, A. 4.1 and A. 4.2.
Rahim (2017) highlighted in their studies that Instagram provided educational opportunities to students for acquisition purposes since the scholars felt relaxed, and that they also stated that through Instagram tasks, learners were able to improve their communicative skills. Additionally, some participants found out that viewing their videos, and seeing the progress they'd achieved within the first and last videos encouraged them to achieve self-confidence and increased their motivation to talk English more which contributed them a way of feat. Furthermore, they mentioned that sharing their videos with their classmates, though gave the impression to be formidable initially, provided them a chance to specific themselves and created the most effective oral performance since others would view their videos.

According to Prasetyo, the sample is an element of the population itself and has certain characteristics to analyze (Prasetyo, and Jannah, 2005: 119). Researchers used sampling as a sampling process. Purposive sampling could be a sampling technique with certain considerations from the sample (Siregar et al 2014: 60). This study used purposive sampling with the consideration that students have passed English 1 course. The sample of this study was 40 fourth semester students majoring in Communication Studies, University of Baturaja.

A test is going to be given to live the students' speaking ability. Researchers provide a specific theme to students, and so, they need to create a speech concept, after recording it into a video, and uploading the videos to their Instagram account. To know students ' perceptions, researchers used 
a questionnaire consisting of 10 questions adopted by Dornyei. The score in choosing the answers to the questionnaire are going to be the most consideration whether Instagram encompasses a positive effect or not on students' speaking ability.Data processing during this study was administrated by processing questionnaire data use quantitative descriptive statistical techniques. The question instruments within the questionnaire are as follows:

Table 1. The Questionnaire Analysis of Student Perceptions towards Use of Instagram in learning English Speaking

\begin{tabular}{|c|c|c|c|c|}
\hline \multirow[t]{2}{*}{ No } & \multirow[t]{2}{*}{ Questions } & $\begin{array}{l}\text { Strongly } \\
\text { agree }\end{array}$ & Agree & Disagree \\
\hline & & 3 & 2 & 1 \\
\hline 1 & Having time to practice English outside the classroom & & & \\
\hline 2 & $\begin{array}{l}\text { Having different atmosphere in practicing English speaking outside the } \\
\text { classroom }\end{array}$ & & & \\
\hline 3 & $\begin{array}{l}\text { Having interesting media to practice English speaking outside the } \\
\text { classroom }\end{array}$ & & & \\
\hline 4 & Wanting English practices outside the classroom & & & \\
\hline 5 & Having motivation to speak English outside the classroom & & & \\
\hline 6 & Feeling confident to speak English outside the classroom & & & \\
\hline 7 & Feeling shy to practice outside the classroom & & & \\
\hline 8 & Enjoying practice outside the classroom & & & \\
\hline 9 & $\begin{array}{l}\text { Having motivation to learn English speaking with friends outside the } \\
\text { classroom }\end{array}$ & & & \\
\hline 10 & Repeating the English lesson materials outside the classroom & & & \\
\hline
\end{tabular}

\section{RESULT AND DISCUSSION}

\subsection{Result}

The data obtained from a questionnaire that had been distributed to 44 students were then analyzed by calculating the amount and percentage. The results of this analysis can be seen in the following table.

Table 2. Result of Questionnaire Analysis of Student Perceptions towards Use of Instagram in learning English speaking

\begin{tabular}{cccc}
\hline \multirow{2}{*}{$\begin{array}{c}\text { State } \\
\text { ments }\end{array}$} & \multicolumn{3}{c}{ Students' Perception } \\
\cline { 2 - 4 } & $\begin{array}{c}\text { Strongly } \\
\text { agree }\end{array}$ & Agree & Disagree \\
$\mathbf{1}$ & $93,2 \%$ & $6,8 \%$ & \\
$\mathbf{2}$ & $84,1 \%$ & $15,9 \%$ & \\
$\mathbf{3}$ & $90,9 \%$ & $9,0 \%$ & \\
$\mathbf{4}$ & $88,6 \%$ & $11,3 \%$ & \\
$\mathbf{5}$ & $90,9 \%$ & $9,0 \%$ & \\
$\mathbf{6}$ & $90,9 \%$ & $9,0 \%$ & \\
$\mathbf{7}$ & $0 \%$ & $11,3 \%$ & $88,6 \%$ \\
$\mathbf{8}$ & $95,5 \%$ & $4,5 \%$ & \\
$\mathbf{9}$ & $100 \%$ & $0 \%$ & \\
$\mathbf{1 0}$ & $95,5 \%$ & $4,5 \%$ & \\
\hline
\end{tabular}

Based on the table, information is obtained about student perceptions of
10 question instruments that show Student Perceptions of the use of Instagram in Learning Speaking in English.First, almost all respondents, as many as $93.2 \%$, strongly agree with the having time to practice English outside the classroom rather than inside the classroom, while $6.8 \%$ of respondents agreed. Second, most of the respondents as much as $84.1 \%$ strongly agree with having a different atmosphere in practicing English outside the classroom, and only $15.9 \%$ of respondents agreed. Third, $90.9 \%$ of respondents strongly agree that was having an interesting medium to practice English outside the classroom, and only $9.0 \%$ of respondents agree. Fourth, $88.6 \%$ stated that they strongly agreed to want to practice English outside the classroom, while the remaining $11.3 \%$ of respondents agreed. Fifth, $90.9 \%$ of respondents have the 
motivation to speak English outside the classroom and only slightly $9.0 \%$ agree. Sixth, the majority of respondents as much as $90.9 \%$ stated that they strongly agreed with feeling confident about speaking English outside the classroom and a few respondents, 9.0\%, agreed. Seventh, $88.6 \%$ of respondents stated that they did not agree with the question, they felt ashamed to practice outside the classroom, while $11.3 \%$ of respondents agreed. Eighth, 95.5\% of respondents stated that they strongly agreed with enjoying the exercise outside of class, while $4.5 \%$ agreed. Nine, all respondents as much as $100 \%$ stated that they strongly agreed with the question having the motivation to learn English with friends outside the classroom. Ten, $95.5 \%$ of respondents stated that they strongly agreed with the question item repeating English subject matter outside the classroom,

\subsection{Discussion}

From the computation of the questionnaire conducted, the researcher found that: (1) students' self-confidence increased when speaking in English, this can be seen that most students often practice speaking outside of lecture hours and there is no shame in continuing to practice with proper pronunciation even though they have articulation. Which is typical in accordance with the culture of origin, (2) students have good motivation to learn to speak in English using social media Instagram. Apart from factors from themselves, students are also motivated by the environment, and their friends. Each student is given the task to upload a video according to a predetermined theme. The popularity of social media has a huge impact on students. Students spend more of their while $4.5 \%$ of respondents said they agreed.

Based on table 2, it can be seen that students gave a positive response to learning to speak in English through the use of social media Instagram. This can be seen from the results of the percentage of 44 respondents who strongly agree with the 10 item questions.

Table.3 Students' Perception toward the use of Instagram on learning English speaking

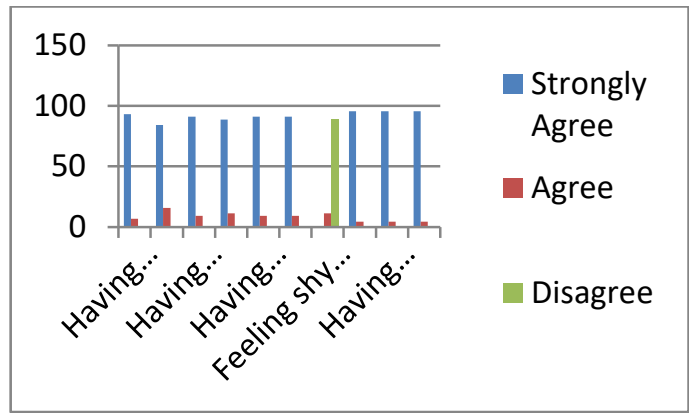

time using social media via their laptops or cellular. Students even have accounts that they manage themselves to interact with friends or new people. Therefore, it can be adapted by teachers or educators to develop certain activities that use social media in language learning. Teachers or educators can actively use Instagram to stay connected with students (Zhang, 2013). (3) The high interest of students in learning to speak in English through the use of social media Instagram. In addition to the students' sense of pride and love for learning English, it turns out that this international language also has various important roles in aspects of life, namely as a career or job support. Having fluency in English can add points to determine a better position or career path when you get a job. 


\section{CONCLUSION}

Based on the results of the research findings, it is concluded that students' perceptions towards the use of Instagram in learning English speaking in the Communication Science Study Program of the Faculty of Social and Political Sciences, Baturaja University has a positive or good response. Instagram can help students improve their speaking ability in English. This showed that Instagram is a learning medium that students like. This is strengthened by the increase in

\section{REFERENCES}

Akdeniz. (2017) Use of studentproduces videos to develop oral skill in EFL classroom. LLOE, 4(1). ISSN 2435-7101 DOI: 10.1515/llce-2017-0003

Alnathalah,A.M.(2016).Problemanddiff icultiesofspeaking thatencounterEnglish languagestudentsatQudsOpenUni versity.JournalofHumanitiesand SocialScience Invention, 5(1), 96101.Retrieved from http://www.ijhssi.org/papers/v5(1 2)/version-3/O5120396101.pdf

Apriyati et all. (2018). Improving students public speaking skill through Instagram. International Conference on Language, Literature, and Education (ICLLE), vol.263. Retrieved from:

https://webcache.googleuserconte nt.com/search?q=cache: wo7OJU xnzpcJ:https://download.atlantisp ress.com/article/55907986.pdf $+\&$ $\underline{\mathrm{cd}=1 \& \mathrm{hl}=\mathrm{id} \& \mathrm{ct}=\mathrm{clnk} \& \mathrm{gl}=\mathrm{id}}$

Bal, E., \& Bicen, H. (2017). The purpose of students' social media use and determining their perspectives on education. self-confidence, learning motivation, and student interest in speaking in English. In the future, it is hoped that learning English courses can use various alternative media by utilizing various digital media. Although the research findings state that the student's response is positive or good towards learning to speak English, it should be noted that students are still constrained about internet access which is sometimes limited by the students.

Procedia Computer Science, 120, 177-181. Retrieved from: https://www.mendeley.com/catal ogue/4cb9c62a-0f82-354a-acda $\underline{6819 \mathrm{~b} 043 \mathrm{~b} 81 \mathrm{e} /}$

Creswell, J.W. (2012). Educational research; planning, conducting, and evaluating quantitative and qualitative research $\left(4^{\text {th }} \mathrm{ed}\right.$.). $\mathrm{New}$ York, NY: Pearson.

Greenhow,C.(2011).OnlineSocialnetwo rksandlearning. OntheHorizon, 19 ( 1),4-12.ISSN: 1074-8121. Retrieved From:https://www.emerald.com/i nsight/content/doi/10.1108/10748 $\underline{121111107663 / \mathrm{full} / \mathrm{html}}$

Handayani,F. (2016).Instagram as ateachingtool?Proceedingof thefourthInternational Seminar on EnglishLlanguage and Teaching. 978-602-74437-0-9-2014

Hirose, S. (1992). Critical thinking in community college. Retrieved from http://www.chaffey.edu/slo/cm_s lo_toolbox/Core\%20Competency $\% 20-$ $\% 20 \mathrm{Critical} \% 20 \mathrm{Thinking} / \mathrm{Critical}$ \%20Thinking\%20in\%20Commu 
nity $\% 20$ Colleges $\% 20$ Shannon $\% 2$ 0Hirose.pdf

Hosni, A. Samira. (2014). Speaking difficulties encountered by young EFL learners. International Journal on Studies in English Language and Literature (IJSELL),2(2), 2-30. Retrieved from: www.arcjournals.org

Kelly, R. (2015). An Exploration of Instagram to Develop ESL Learners' Writing Proficiency.UnpublishedMaster's Dissertation.BritishCouncil:Ulster University. Retrieved from: https://englishagenda.britishcounc il.org/sites/default/files/attachmen ts/dissertation_for_publication_uls ter_university.pdf

Lenhart, A., Purcell, L., Smith, A., \&Zickuhr, K. (2010).Social media and young adults. PewInternet and American Life Project.

Retrievedfromhttp://www.pewinte rnet.org/Reports/2010/SocialMedia-and-Young-Adults.aspx

Listiani,G.(2016).TheEffectivenessofIn stagramWritingComparedtoTeac her-centered Writing toTeachRecountTexttoStudentsW ith

HighandLowMotivation(TheCase of Eight GradeStudents inSMPKesatrian 1 Semarangin theAcademicYear of 2015/2016). ELTFORUM,5(1).Retrievedfrom: https://journal.unnes.ac.id/sju/ind ex.php/elt/article/view/9875

Littlewood,W.(1984).Foreignandsecond languagelearning.Cambridge: $\mathrm{Ca}$ mbridgeUniversityPress

Mansor,N.,\&Rahim,N.A.(2017).Instagr aminESLClassroom.ManinIndia, 9 $7(20)$, 107-114.
Retrieced

from:https://www.researchgate.net /publication/321016352_INSTAG RAM IN ESL CLASSROOM? nrichId=rgreq6baa $14 \mathrm{cacc} 82 \mathrm{f} 21 \mathrm{c} 7$ 8efafe9fcc5f9deXXX\&enrichSour ce $=$ Y292ZXJQYWdlOzMyMTAx NjM1MjtBUzo1NTk3MTc1MDE xNDkxODRAMTUxMDQ1ODQ 10TIzMQ\%3D\%3D\&el=1_x_2\& _esc=publicationCoverPdf

Nasrullah, Rulli. (2015). Media Sosial :Perspektifkomunikasi, BudayadanSosioteknologi. Bandung: Rosdakarya.

Nirmawati, L. Amalia.(2015). Improving students' speaking skills through speaking board game of grade VIII of SMP N 13 Yogyakarta in the academic year 2013/2014.Faculty of Language and Arts. Yogyakarta State University. (Unpublished thesis)

Nunan, D. (1992). Research method in language learning.Cambridge, NY: Cambridge Language Teaching Library.

Okada, Y., Sawaumi, T., \& Ito, T. (2014). Different effects of sample performance observation between high and low proficiency English learners. In Aishah M. K., W. M. Chan, S. W. Chi, K. N. Chin, S. Klayklueng, S. Kumar Bhatt, M. Nagami, J. W. Sew, T. Suthiwan, \& I. Walker, (Comps.), Knowledge, Skills and Competencies in Foreign Language Education. Proceedings of the 6th CLS International Conference (pp. 394- 413). Singapore: National University of Singapore, Centre for Language Studies. Retrieved from 
http://www.fas.nus.edu.sg/cls/CL aSIC/clasic2014/Proceedings/

Prasetyo, B., \&Jannah, L. M. (2005).MetodePenelitianKuantitat if:

TeoridanAplikasi.PT.RajaGrafind oPersada Published, Jakarta

Siregar \& Syofian. (2014). Metode Penelitian Kuantitatif. Kencana Published, Jakarta

Sari,N.Ardila.(2017).Students'difficulti esinspeakingskillattheeleventhgra deofSMA

MuhammadiyahIKarang Anyarin the academicyearof 2016/2017.(unpublished thesis). StateIslamicInstituteof Surakarta

Tarigan,

$\mathrm{H}$.

(2013).

BerbicaraSebagaiSuatuKeterampi lanBerbahasa. Bandung: Angkasa.

Ur, P. (1991). A course in language teaching: Practice and theory. Cambridge: Cambridge University Press.

Wiktor,K.(2012).ABillionDollarIdea:Ins tagramandLanguageLearning.Retr ieved from: https://bravelearning.com/2012/04 /20/a-billion-dollar-ideainstagram-and-language-learning/

WorldBank.(2010).Indonesiaskillreport :Trendsinskillsdemandgap,andsup plyinIndonesia.

Retrieved from http://siteresources.worldbank.org /EASTASIAPACIFICEXT/Resou rces/2263001279680449418/HigherEd_Indon esiaSkillReport.pdf

Zhang, S. (2009).The role of input, interaction, and output in the development of oral fluency.English Language
Teaching, 2(4), 91-100. Retrieved from:

https://pdfs.semanticscholar.org/d $\underline{3 d 3 / 257374693 b f 714 c 2 c b 8 f 6 a 311}$ d31cc17ec12.pdf 
